Artykuly / Articles

Maria Hapunik

ORCID: 0000-0002-4522-0563

mariahapunik@wp.pl

Komenda Wojewódzka Policji w Białymstoku

\title{
Środki inwigilacji cudzoziemców w demokratycznym państwie prawa
}

\author{
Means of Surveillance of Immigrants \\ in a Democratic State of Law
}

DOI: 10.34739/doc.2021.18.13

\begin{abstract}
Abstrakt: W artykule poruszona została tematyka dotycząca działań prewencyjnych służb państwowych, podejmowanych $\mathrm{w}$ ramach walki $z$ terroryzmem, przede wszystkim w stosunku do cudzoziemców. Warunkiem sine qua non wypełniania przez służby zadań dotyczących zapewnienia szeroko rozumianego bezpieczeństwa jest dysponowanie przez nie zasobem relewantnych informacji. $\mathrm{W}$ demokratycznym państwie prawa nieograniczone uzyskiwanie informacji przez przedmiotowe służby nie jest możliwe. Temat poniższych rozważań nie jest nowy, oscyluje on pomiędzy standardami społeczeństwa obywatelskiego, a bezpieczeństwem publicznym w kontekście geopolitycznym, czyli aktami terroryzmu i współczesnym kryzysem migracyjnym w Unii Europejskiej.
\end{abstract}

Słowa kluczowe: kryzys migracyjny, terroryzm, bezpieczeństwo publiczne, środki inwigilacji

Abstract: The article raises the subject of prevention actions taken in the fight against terrorism, directed mainly against foreigners. The sine qua non condition to be fulfilled by state services to ensure broadly defined security is to have the resource of relevant information at their disposal. In a democratic state of law, for the services in question to obtain unrestricted information is not possible. The subject of following reflections is not new; it oscillates between the standards of a civil society and public safety in the geopolitical context, acts of terrorism and contemporary migrant crisis in the European Union.

Keywords: migrant crisis, terrorism, public safety, surveillance measures

Współcześnie doświadczana społecznie globalizacja oraz intensywna transmisja kulturowa stanowi przyczynę do badań nad 
wzajemnymi interakcjami zjawisk społecznych. Obserwowane nasilenie się fali migracji do Europy determinuje nowe zagrożenia. Analizując istotne zmiany, które zachodzą w poszczególnych społeczeństwach, w tym również w Polsce, należy zadać sobie pytania: na ile pojawienie się w naszym kraju coraz większej liczby cudzoziemców może wpływać na zwiększenie ich udziału w zjawisku przestępczości? Do jakich nowych zagrożeń przygotować się powinny, a przede wszystkim im przeciwdziałać, wszystkie służby państwowe, odpowiedzialne za szeroko pojęte bezpieczeństwo w Polsce oraz w Unii Europejskiej?

Napływający na Stary Kontynent uchodźcy i imigranci, $z$ racji swojego północnoafrykańskiego lub bliskowschodniego pochodzenia (sa to obszary największej aktywności organizacji terrorystycznych), zintensyfikuja ryzyko radykalizacji społeczności muzułmańskich na terenie Europy, a co za tym idzie - również aktywność terrorystyczna islamistów. W tym kontekście mniejszym zagrożeniem wydają się ewentualne fale niekontrolowanej migracji z Azji, Bałkanów i Ukrainy. Członkowie wspomnianych diaspor nie wchodzili bowiem w skład komórek terrorystycznych (dziś powiazanych z Al-Kaida lub ISIS), które od początku lat 90. przygotowywały zamachy w Europie ${ }^{1}$. Mniejsze zagrożenie związane jest również z migrantami (a także ich potomkami) z Afryki Subsaharyjskiej, choć w ostatnich latach w składzie komórek terrorystycznych, dokonujących także ataków w Europie, pojawiły się np. osoby pochodzenie nigeryjskiego ${ }^{2}$.

Nieefektywna kontrola migrantów w południowych państwach Starego Kontynentu niesie ze soba realne zagrożenie bezpieczeństwa w Unii Europejskiej, również w Polsce. Nie wydaje się, aby można było całkowicie wykluczyć obecność w naszym kraju członków bliskowschodnich grup terrorystycznych, rebelianckich i zbrojnych, przebywajacych na terytorium Polski w celu wspierania materialnego swoich towarzyszy, toczacych walki (przykładowo na frontach w Syrii). Panujacy w społeczeństwie polskim brak entuzjazmu wobec imigrantów oraz ich potomstwa może inicjować ich radykalizację, na co nałożyć się moga dodatkowo działania propagandowe Al-Kaidy i ISIS, które odpowiednio od 1998 i 2013 roku nawołuja do ataków

1 Niekontrolowane migracje do Unii Europejskiej - implikacje dla Polski, red. P. Sasnal, Warszawa 2015, s. 50.

2 Ibidem. 
w Europie. W efekcie niektórzy radykalizujacy się islamiści moga pominąc etap skierowania swojego gniewu na kraje pochodzenia (np. Syria), i przejść od razu do działań nielegalnych i terrorystycznych, wymierzonych w bezpieczeństwo kraju przebywania ${ }^{3}$.

Narastanie postaw ksenofobicznych połączone jest niewątpliwie ze wzmożona intensywnością zjawisk imigracyjnych przy braku programów integracyjnych i debaty społecznej na temat różnorakich skutków, zarówno pozytywnych, jak i negatywnych, napływu imigrantów dla społeczeństwa przyjmującego ${ }^{4}$. Ksenofobia objawia się w postaci ataków na cudzoziemców, a także w antyunijnych hasłach partii politycznych (migracja stanowi ważna płaszczyznę kampanii politycznych, w których często brane sa pod uwage stereotypy). Istotnym jest również fakt, iż po II wojnie światowej społeczeństwo polskie stało się homogenicze etnicznie, $z$ ograniczonymi możliwościami uczenia się współżycia i obcowania $z$ innymi kulturami.

Migracja ludności jest procesem nie do powstrzymania. Trwa od wieków. Współcześnie utrwala go i wzmacnia postępująca globalizacja. Obecny kryzys, zwiazany $z$ przybywaniem imigrantów i uchodźców do Unii Europejskiej, posiada przede wszystkim wymiar instytucjonalny i polityczny. $Z$ uwagi na niechętne przybyszom postawy większości europejskich społeczeństw oraz na niewydolność systemowych instrumentów sytuacja ta doprowadziła do sprawdzenia trwałości i jedności Unii. Zapaść humanitarna na bliskim Wschodzie, a także inercja społeczności międzynarodowej przyczyniły się do kryzysu migracyjnego o niespotykanych dotąd rozmiarach.

Warunkiem sine qua non wypełniania przez służby państwowe zadań dotyczacych zapewnienia szeroko rozumianego bezpieczeństwa jest dysponowanie przez nie zasobem relewantnych informacji. W demokratycznym państwie prawa nieograniczone uzyskiwanie informacji przez przedmiotowe służby nie jest oczywiście możliwe. Wzgląd na różne chronione wartości skłania ustawodawcę do ograniczania możliwości zbierania informacji przez służby państwowe. Podstawy ochrony dóbr zawarte są w Europejskiej Konwencji Praw Człowieka i Podstawowych Wolności oraz w poszczególnych aktach normatywnych krajów członkowskich. W Polsce ograniczenia

\footnotetext{
3 Ibidem, s. 54.

${ }^{4} \mathrm{~K}$. Iglicka, Unijny wymiar bezpieczeństwa $z$ perspektywy migracji międzynarodowych i dylematów wielokulturowości, „Raporty i Analizy” 2004, nr 7, s. 2 i n.
} 
wobec suwerena wynikaja $z$ Konstytucji. I tak art. 31 mówi o zasadzie niezbędności w przypadku naruszeń praw podstawowych, art. 47 o prawie do prywatności, art. 49 chroni tajemnicę korespondencji, art. 51 gwarantuje ochronę danych osobowych ${ }^{5}$.

Procedura ważenia pozostających w kolizji wartości, takich jak bezpieczeństwo i prawa podstawowe, jest wyjątkowo skomplikowana, często również nieoczywista. Unormowania dotyczące gromadzenia i przetwarzania danych o obywatelach przez służby państwowe sa dyskutowane i często kontestowane. Protesty przeciwko inwigilacji łącza się nawet $z$ kwestionowaniem praworządności działań aparatu kontroli społecznej i bezpieczeństwa państwa. Widoczne jest, iż problemy polityczne i prawne zwiazane sa przede wszystkim z działaniami prewencyjnymi służb państwowych, podejmowanymi $\mathrm{w}$ ramach walki $z$ terroryzmem. Prewencyjnie zorientowane cele masowej inwigilacji opartej na analizie terabajtów danych cechuje odmienne podejście do roli informacji jako czynnika warunkującego skuteczność działań organów odpowiedzialnych za bezpieczeństwo państwa. Celem działania tych organów jest niedopuszczenie do zamachu terrorystycznego lub innego niepożądanego $z$ punktu widzenia bezpieczeństwa publicznego zdarzenia. Priorytetem nie jest natomiast doprowadzenie do wykrycia i ukarania sprawcy zamachu, co jest zadaniem organów ścigania i wymaga od nich zgromadzenia $\mathrm{i}$ analizy informacji $\mathrm{w}$ celach dowodowych ${ }^{6}$. Współcześnie służby specjalne w swych działaniach odchodza od ukierunkowanego nadzoru, prowadząc inwigilację o skali masowej. Zwiazane jest to niewątpliwie $z$ postępem technicznym oraz prowadzeniem proaktywnej walki $z$ terroryzmem. Model takiego działania opiera się na założeniu, iż ochrona bezpieczeństwa publicznego jest niemożliwa bez ingerencji w prawa podstawowe. Czynności operacyjne prowadzone sa nie tylko wobec aktualnych lub potencjalnych przestępców, ale także wśród wszystkich obywateli, niezaangażowanych w działalność niezgodna $z$ prawem.

\footnotetext{
5 Konwencja o Ochronie Praw Człowieka i Podstawowych Wolności sporządzona w Rzymie dnia 4 listopada 1950 r., zmieniona następnie Protokołami nr 3, 5 i 8 oraz uzupełniona Protokołem nr 2, Dz.U. 1993 nr 61, poz. 284.

6 A. Adamski, Dane telekomunikacyjne jako środek inwigilacji masowej $w$ demokratycznym państwie prawa, [w:] Jawność i jej ograniczenia, T. X, Przeciwdziałanie przestępczości, red. J. Majewski, G. Szpor, Warszawa 2015, s. 6.
} 
Przykład założenia działań prewencyjnych służb specjalnych przedstawił, jako model profilowania potencjalnego terrorysty, Robert O’Harrow Jr.. Zakładając, że dotyczy to profilu terrorysty przebywającego w Holandii (16 mln mieszkańców), pochodzącego spoza Europy Zachodniej (1,7 mln mieszkańców), będącego wyznawca islamu (850 tys. mieszkańców) i należącego do drugiego pokolenia imigrantów (147 tys. mieszkańców), przyjmuje się, że jeden procent osób odpowiadających temu profilowi tworza ekstremiści ${ }^{7}$. Jeśli spośród tej grupy kolejne 10\% osób może być poważnym zagrożeniem dla reszty społeczeństwa, to na podstawie opracowanego profilu i przyjętych założeń 147 osób należy poddać inwigilacji. W praktyce oznacza to, że większość $z$ nich, faktycznie bez powodu, zostanie pozbawiona części prywatności ${ }^{8}$.

Funkcja demokratycznego państwa nie jest jednak jedynie ochrona praw i wolności, ale również zwalczanie zjawisk, które godza w samo istnienie państwa. Koniecznym wydaje się prowadzenie systematycznej analizy wpływu migracji na bezpieczeństwo wewnętrzne państwa oraz rewizja istniejacych w Polsce strategii przeciwdziałania terroryzmowi oraz zapobiegania radykalizacji i rekrutacji do organizacji terrorystycznych. Należy wziąc pod uwage, iż liczba napływających do Polski migrantów z krajów muzułmańskich ulega zwiększeniu i dlatego niezbędne jest opracowanie oraz wdrożenie narodowego programu w zakresie form zapobiegania terroryzmowi, a także zwalczania go. W celu przeciwdziałania tym zagrożeniom koniecznościa wydaje się wzmacnianie Frontexu, jak również ścisła współpraca służb zwiazanych $z$ zapewnieniem bezpieczeństwa poszczególnych państw członkowskich. W tym kontekście istotnym jest również opracowanie regulacji krajowych i unijnych dotyczacych mechanizmów determinujących tę sferę. W zakresie przeciwdziałania terroryzmowi istotne jest stanowienie regulacji uruchamiajacych efektywne i skuteczne działanie antyterrorystyczne, jak również usprawniające i ujednolicajace jego mechanizmy.

Przykładem takiego działania organów państwowych jest uchwalenie przez polski parlament ustawy o działaniach antyterro-

\footnotetext{
7 R. O’Harrow Jr., No Place to Hide, s. 139, cyt. za: ibidem, s. 2.

8 Ibidem.
} 
rystycznych ${ }^{9}$. Negowany jest $\mathrm{i}$ był tryb procedowania przedmiotowej ustawy, a przede wszystkim zawarcie w niej rozwiazań polegajacych na przyznaniu służbom państwowym uprawnień do wkraczania w prawa i wolności obywateli, niepodlegających niezależnej kontroli zewnętrznej. $Z$ cała pewnością stwierdzić jednak należy, iż powyższa ustawa jest niezbędna w polskim porządku prawnym. Wielu ekspertów czekało na ten akt normatywny od lat, podobnie jak na nieuchwaloną do dzisiaj ustawę o czynnościach operacyjno-rozpoznawczych. Według twórców ustawy o działaniach antyterrorystycznych najważniejszym celem tego aktu jest lepsza koordynacja służb odpowiedzialnych za bezpieczeństwo publiczne, ponadto umożliwienie służbom nie tylko skutecznego i sprawnego, ale również szybkiego działania. Nowe regulacje doprecyzowały zadania poszczególnych służb państwowych, a także zasady współpracy pomiędzy nimi. Celem ustawy było również dostosowanie polskich przepisów karnych do nowych typów zagrożeń o charakterze terrorystycznym.

Według Ministerstwa Spraw Wewnętrznych i Administracji najważniejsze zmiany to wprowadzenie przez ustawę o działaniach antyterrorystycznych powszechnie obowiązujacego i dostosowanego do wymogów NATO czterostopniowego systemu stopni alarmowych na wypadek zagrożeń terrorystycznych. Nowościa jest ustanowienie stopni alarmowych CRP dla zagrożeń terrorystycznych w cyberprzestrzeni. Przedmiotowy akt prawny odpowiedzialność za zapobieganie terroryzmowi jednoznacznie przypisał szefowi Agencji Bezpieczeństwa Wewnętrznego (dalej: ABW). Przyznane ustawa kompetencje pozwalaja szefowi ABW prowadzić wykaz osób, mogących mieć związek ze zdarzeniami o charakterze terrorystycznym. Ponadto ABW otrzymało dostęp do danych i informacji zgromadzonych w rejestrach i ewidencjach państwowych, także tych, które sa prowadzone przez inne organy, służby czy podmioty, w tym także samorządy. Przepisy ustawy o działaniach antyterrorystycznych gwarantuja także dostęp ABW do obrazów $z$ monitoringów umieszczonych w miejscach publicznych. Szef przedmiotowej służby będzie mógł ponadto uzyskiwać dostęp do przetwarzanych przez banki informacji, które stanowia tajemnicę bankową oraz informacji dotyczących umów

9 Ustawa z dnia 10 czerwca 2016 roku o działaniach antyterrorystycznych, Dz.U. 2016, poz. 904. 
o rachunek papierów wartościowych, umów i danych osób, które je zawarły, a także do danych dotyczacych obrotu instrumentami finansowymi będacych tajemnica zawodowa. Wynika stąd, że to Szefowi ABW przyznano kompetencje do koordynacji czynności analityczno-informacyjnych, a także do wymiany informacji między poszczególnymi służbami, dotyczących zagrożeń o charakterze terrorystycznym ${ }^{10}$.

Szefom ABW oraz SKW nowa ustawa przyznała również prawo wnioskowania do Ministra Spraw Wewnętrznych i Administracji o wydanie decyzji o natychmiastowym wydaleniu $z$ kraju cudzoziemca, mogącego prowadzić działalność terrorystyczną lub szpiegowska, albo podejrzewanego o popełnienie jednego $z$ tych przestępstw. $\mathrm{Na}$ podjęcie przez uprawnione organy działań przewidzianych w omawianej ustawie pozwalać będzie wystapienie zdarzeń określonych w katalogu incydentów o charakterze terrorystycznym, zawartym w Rozporządzeniu Ministra Spraw Wewnętrznych i Administracji $z$ dnia 22 lipca 2016 roku $^{11}$ i posiadajacym delegację ustawowa w postaci art. 5 ust. 2 ustawy z dnia 10 czerwca 2016 r. o działaniach antyterrorystycznych. Katalog ocenić można jako szczegółowy. Podzielony został na części, określające rodzaje incydentów. Omawiany akt wykonawczy wskazuje na rodzaje informacji, które sa niezbędne w celu prowadzenia czynności informatyczno-analitycznych oraz prowadzenia zbiorów danych o osobach pozostajacych w zainteresowaniu uprawnionych służb.

Kolejnym z narzędzi, majacym na celu umożliwienie służbom państwowym zapewnienie bezpieczeństwa publicznego, jest wprowadzenie przez ustawę o działaniach antyterrorystycznych kompetencji do prowadzenia kontroli operacyjnej wobec cudzoziemców. Ustawa nie posługuje się jednak określeniem „kontrola operacyjna”, pomimo iż przedmiot kompetencji pokrywa się z, przykładowo, art. 19 ustawy o Policji. Zasadniczą różnica jest natomiast brak sądowej kontroli nad ta czynnością operacyjna i powierzenie jej Prokuratorowi Generalnemu. Istotne jest to, iż potocznie nazywany „podsłuch” wobec

10 Ustawa antyterrorystyczna - skuteczne $i$ sprawne działanie służb, https://mswia. gov.pl/pl/aktualnosci/ 14490,Ustawa-antyterrorystyczna-skuteczne-i-sprawnedzialanie-sluzb.html?search=83945 (data dostępu: 02.09.2020).

11 Rozporządzenie Ministra Spraw Wewnętrznych i Administracji z dnia 22 lipca 2016 roku w sprawie w sprawie katalogu incydentów o charakterze terrorystycznym, Dz.U. 2016, poz. 1092. 
cudzoziemców prowadzić można na podstawie ustaw kompetencyjnych poszczególnych służb, jak i ustawy o działaniach antyterrorystycznych „w celu rozpoznawania, zapobiegania lub zwalczania przestępstw o charakterze terrorystycznym"12. Cytowany powyżej art. 9 omawianej ustawy dotyczy wyłącznie cudzoziemców, w stosunku do których „istnieje obawa” prowadzenia działalności zwiąanej z terroryzmem. Przepis art. 10 przewiduje dostęp Policji, Straży Granicznej oraz ABW do danych biometrycznych cudzoziemców, czyli obrazu linii papilarnych i wizerunku twarzy. Przesłankami do zastosowania powyższego przepisu będzie wątpliwość co do tożsamości osoby, podejrzenie nielegalnego przekroczenia granicy lub wattpliwość co do celu przebywania na terytorium Rzeczypospolitej Polskiej, a także istnienie podejrzenia co do zamiaru nielegalnego przebywania na jej terytorium. Przepis ten ma również zastosowanie w odniesieniu do cudzoziemców podejrzanych o zwiazek ze zdarzeniem terrorystycznym lub szkoleniem terrorystycznym ${ }^{13}$.

Rozszerzanie uprawnień służb policyjnych do gromadzenia i przetwarzania danych osobowych jest ogólnoświatowym trendem, spowodowanym zagrożeniem terrorystycznym. W latach 2001-2006 w USA zwiększono uprawnienia FBI, CIA i NSA przy jednoczesnym ograniczeniu kontroli sądowej nad ingerencja państwa w sferę prywatności. Nowe ustawodawstwo antyterrorystyczne USA umożliwiło amerykańskim służbom specjalnym podjęcie działań wywiadowczych na niespotykaną wcześniej skalę. Również Wielka Brytania, podobnie jak USA, na pierwszym miejscu stawia szeroko pojęte bezpieczeństwo obywateli, dając szerokie uprawnienia służbom. Od 2007 r. w Wielkiej Brytanii obowiazuje przyjęta przez Parlament już w 2000 r. ustawa The Regulation of Investigatory Powers Act (RIPA). Ustawa ta w Section 49 of Part III w przypadku określonych najpoważniejszych przestępstw (m.in. przestępstwa terrorystyczne, przeciwko bezpieczeństwu publicznemu, pedofilii, przestępczości zorganizowanej) normuje obowiązek każdego obywatela, stosującego technologie szyfrujące, ujawnienia na żądanie odpowiednich władz sposobu szyfrowania przez siebie danych (czyli sposób deszyfracji) albo samodzielnego odszyfrowania danych (put into an intelligible

12 Ustawa $z$ dnia 6 kwietnia 1990 r. o Policji, Dz. U. 2020, poz. 360 t.j.

13 Ibidem. 
form). Osoba otrzymująca przedmiotowe żądanie od władz nie może ujawnić tego faktu nikomu, poza swoim adwokatem ${ }^{14}$.

Dnia 17 lipca 2014 roku, w trybie nadzwyczajnym, przyjęta została w Wielkiej Brytanii ustawa Data Renention and Investigatory Powers Bill (DRIP). Ustawa została uchwalona w ekspresowym tempie, który usprawiedliwiano przerwa wakacyjna parlamentu. W sprawie niniejszej ustawy porozumieli się trzej liderzy największych partii w parlamencie Wielkiej Brytanii (w tym opozycyjna Partia Pracy), którzy uznali, że nie można odkładać w czasie jej uchwalenia. Ówczesny premier Wielkiej Brytanii David Cameron doprowadził do przyjęcia ustawy o retencji, posiłkując się argumentami takimi jak ściganie i ochrona przed pedofilami, mordercami, a także niespokojna sytuacja na Bliskim Wschodzie ${ }^{15}$. Ustawa przywróciła stan prawny sprzed orzeczenia Trybunału Sprawiedliwości Unii Europejskiej $z$ dnia 8 kwietnia 2014 roku, które unieważniło dyrektywę 2006/24/WE Parlamentu Europejskiego i Rady z dnia 15 marca 2006 r. w sprawie zatrzymywania generowanych lub przetwarzanych danych w zwiazku ze świadczeniem ogólnie dostępnych usług łączności elektronicznej lub udostępnianiem publicznych sieci łączności oraz zmieniająca dyrektywę 2002/58/WE. W styczniu 2018 r. brytyjski sąd apelacyjny uznał powyższą ustawę DRIPA - ustawę obejmująca nadzór państwowy, która została rozszerzona o ustawę o uprawnieniach dochodzeniowych z 2016 r. - za niezgodna z prawem. Nowe przepisy dotyczace retencji i pozyskiwania danych 31 października 2018 r. weszły w życie na terenie Wielkiej Brytanii ${ }^{16}$.

W dniu 24 czerwca 2015 roku (pół roku po ataku na pracowników redakcji „Charlie Hebdo”) francuski parlament przyją ustawę zwiększająca kompetencje służb. Ponadto Francuska Rada Konstytucyjna stwierdziła, iż nowa ustawa jest zgodna $z$ konstytucją. Przepisy powyższej ustawy w znacznym stopniu rozszerzaja uprawnienia służb w zakresie monitorowania danych telekomunikacyjnych oraz teleinformatycznych osób podejrzewanych o terro-

14 Regulation of Investigatory Powers Act 2000, https://www.legislation.gov.uk/ ukpga/2000/23/contents (data dostępu: 20.01.2021).

15 Wielka Brytania: Wyrzekanie sie wartości $w$ obliczu terroryzmu, https://www.libertieseu/pl/stories/wyrzekanie-sie-wartosci-wielka-brytania/3019 (data dostępu: 10.04.2021).

16 Data Retention and Investigatory Powers Act 2014, https://www.legislation. gov.uk/ukpga/2014/27/contents/enacted (data dostępu: 20.01.2021). 
ryzm. Umożliwia ona między innymi automatyczne namierzanie podejrzanych treści w sieci za pomoca algorytmów oraz instalację złośliwego oprogramowania w komputerach, celem przejęcia kontroli nad urzadzeniami typu kamera czy zmianę haseł. Działania operacyjne podlegaja kontroli specjalnej komisji, która składa się $z$ dziewięciu osób, jej przewodniczącym jest francuski premier ${ }^{17}$. Przepisy wspomnianej ustawy wzmocniły krajowe ramy prawne dla wywiadu we Francji, wprowadzając wiele kontrowersyjnych środków w obszarze prywatności obywateli. Jednocześnie od 30 października 2017 r. obowiazuje nowa ustawa antyterrorystyczna, oceniana przez dużą część społeczeństwa we Francji jako represyjna. Ustawa została wprowadzona na trzy lata, jednak w lipcu 2020 r. Zgromadzenie Narodowe, niższa izba francuskiego parlamentu, zagłosowało za przedłużeniem jej obowiązywania do końca lipca 2021 r. ${ }^{18}$

Także w Republice Federalnej Niemiec od 2009 r. Federalny Urząd Kryminalny (BKA) dysponuje szerokimi uprawnieniami wykorzystywanymi w walce $z$ terroryzmem. W myśl przyjętej w RFN ustawy antyterrorystycznej, służby państwowe moga uzyskiwać i utrwalać treść rozmów prowadzonych za pomoca środków technicznych, a także uzyskiwać i utrwalać obrazy lub dźwięk osób z miejsc innych niż publiczne, jeżeli ma to służyć zapobieganiu i walce $z$ terroryzmem. Nowela przedmiotowej ustawy poszerzyła uprawnienia BKA o możliwość utworzenia oraz korzystania $z$ tzw. „konia trojańskiego", czyli Bundestrojaner - programu, umożliwiającego kontrolę komputerów osób powiazanych $z$ organizacjami terrorystycznymi lub podejrzewanych o działalność terrorystyczną. W kwietniu 2016 r. Federalny Trybunał Konstytucyjny w Karlsruhe orzekł, że przedmiotowa ustawa jest niezgodna $z$ niemiecka konstytucją. Trybunał wydał szereg wytycznych, które pozwalaja tymczasowo BKA na posługiwanie się dotychczasowymi uprawnieniami, jednocześnie zobowiązujac ustawodawce do zmiany niezgodnych $z$ konstytucja przepisów do końca czerwca 2018 r. ${ }^{19}$.

\footnotetext{
17 Francja poszerza kompetencje stużb, https://panoptykon.org/wiadomosc/ francja-poszerza-kompetencje-sluzb (data dostępu: 10.04.2021).

$18 \mathrm{PAP} / \mathrm{IS} 24$, Francja przedłuża obowiazywanie kontrowersyjnej ustawy antyterrorystycznej, https://www.infosecurity24.pl/francja-przedluza-obowiazywaniekontrowersyjnej-ustawy-antyterrorystycznej (data dostępu: 20.12.2020).

19 E. Stasik, Niemcy: Ustawa antyterrorystyczna $w$ znacznym stopniu niezgodna $z$ konstytucja, https://www.dw.com/pl/niemcy-ustawa-antyterrorystyczna-w-
} 
Coraz częściej słyszy się zdanie „governments will hack”, co znaczy, że rządy będa łamać zabezpieczenia, będą inwigilować. To zdanie, choć brzmi bezkompromisowo, w bardzo skondensowany i prawdziwy sposób przedstawia zachowanie służb państwowych, stworzonych i zobowiazanych do zapewnienia bezpieczeństwa publicznego. Czy permanentne poszerzanie prawa do inwigilacji służy poprawie bezpieczeństwa? Według Williama Binneya praktyka ta nie poprawia bezpieczeństwa, jest bezcelowa, a nawet szkodliwa. Gromadzenie terabajtów przypadkowych danych przez NSA nie przynosi wymiernych i oczekiwanych efektów, gdyż Agencja nie jest w stanie takiej ich ilości analizować. Każdego dnia zatrzymywane są dane telekomunikacyjne około czterech miliardów ludzi, takie jak lokalizacje, wykazy połączeń telefonicznych i internetowych, włączając w to treść przekazów, czyli rozmów, SMS-ów i e-maili. $Z$ informacji przekazywanych przez Binneya, jeden pracownik Agencji musiałby skontrolować dziennie 200 tys. osób. W takiej sytuacji funkcjonariusze służb zarzucają analizę kierunkowa, tak naprawdę jedyna, która realnie jest w stanie wskazać na konkretne zagrożenie. Realizowana jest natomiast procedura prostego przeszukiwania baz danych według słów-kluczy ${ }^{20}$. To daje ogromne liczby „trafień”, które nie zawieraja istotnych informacji o powiazaniach między danymi. Przykładem jest fiasko prowadzenia amerykańskiego programu ESCHELON, przechwytującego miliony przekazów informacji, filtrowanych według słów-kluczy. Program nie był w stanie zapobiec wydarzeniom 11 września 2001 r. Według Binneya był to też powód niewykrycia planowanego przez braci Carnajewów zamachu podczas maratonu w Bostonie. NSA była w posiadaniu ich korespondencji mailowej oraz rozmów telefonicznych, a rosyjskie służby przekazały Amerykanom informacje ostrzegające o starszym $z$ braci. Ogromne ilości danych przeszukiwane sa na zasadzie internetowych wyszukiwarek, a na etapie ich analizy nie włącza się danych pozyskanych od informatorów. Przykładem kolejnej porażki amerykańskich służb specjalnych jest niewykrycie planowanego zamachu na uczestników konkursu karykatur Mahometa. Dwóch terrorystów planowało za-

znacznym-stopniu-niezgodna-z-konstytucj\%C4\%85/a-19201601 (data dostępu: 10 kwietnia 2021).

20 W. Binney, Podsłuch rzadzi strachem (wywiad przeprowadzony przez E. Siedlecka i K. Szymielewicz), http://wyborcza.pl/magazyn/1,124059,17924695,Podsluch _rzadzi_strachem.html (data dostępu: 10.08.2020). 
strzelić jak najwięcej uczestników powyższego konkursu. Planowany zamach wykryli hakerzy $z$ grupy Anonymous na podstawie inteligentnej analizy powiazań, na dwa dni przed zamachem powiadamiając policję. NSA, posiadając identyczne dane, nie potrafiła dotrzeć do zamachowców ${ }^{21}$.

Były funkcjonariusz Agencji twierdzi, że żaden $z$ dotychczasowych zamachów lub prób zamachów w Stanach Zjednoczonych nie został wykryty i powstrzymany dzięki masowemu przetwarzaniu danych telekomunikacyjnych, a jeśli dochodzi do skutecznej interwencji, jest to efektem działania informatorów oraz innych służb. Ponadto według Binneya gromadzone masowo dane moga być przydatne, ale na późniejszym etapie podczas analizy kryminalistycznej, mającej na celu wyjaśnienie, w jaki sposób planowano i zrealizowano atak. Potencjał obronny państwa osłabiany jest poprzez nieprofesjonalna pracę służb specjalnych, rażąca jest również fasadowa kontrola nad służbami. Organy kontroli sa nieskuteczne w swych działaniach, bo ich wiedza opiera się na informacjach przekazywanych im przez same służby ${ }^{22}$.

Reasumując należy stwierdzić, że bezpieczeństwo publiczne jest niewątpliwie powodem, który uzasadnia w sposób wystarczajacy ingerencje $\mathrm{w}$ prawa do ochrony danych osobowych oraz w prawa do prywatności obywateli. Nie oznacza to jednak zezwolenia, biorac pod uwage dorobek europejskiej kultury prawnej, na nieograniczona inwigilację. Najważniejszymi z przewag służb specjalnych lub służb policyjnych jest nadal, pomimo fenomenalnego rozwoju technologii ICT, dobre zakorzenienie w społeczeństwie oraz umiejętność gromadzenia informacji według klasycznej wiedzy o sztuce pracy operacyjnej. Mnogość możliwości i narzędzi pozostających w rękach służb nie decyduje o ich skuteczności. Przy rosnacej liczbie możliwości łatwiej ulega się złudzeniu własnej wszechwiedzy. Wielość narzędzi i możliwości przyczynia się do braku skoordynowania działań. Jest to powracajace doświadczenie służb $z$ różnych stron świata. Pomimo posiadania informacji na temat zagrożenia, które pozwoliłyby zidentyfikować przyszłych sprawców, nie udało się uniknąć wielu tragedii.

\footnotetext{
21 Ibidem.

22 Ibidem.
} 
Bibliografia / References

Adamski A., Dane telekomunikacyjne jako środek inwigilacji masowej $w$ demokratycznym państwie prawa, [w:] Jawność i jej ograniczenia, T. X, Przeciwdziałanie przestępczości, red. J. Majewski, G. Szpor, Warszawa 2015.

Iglicka K., Unijny wymiar bezpieczeństwa $z$ perspektywy migracji międzynarodowych $i$ dylematów wielokulturowości, „Raporty i Analizy”, 2004, nr 7 .

Niekontrolowane migracje do Unii Europejskiej - implikacje dla Polski, red. P. Sasnal, Warszawa 2015.

Akty prawne / Legal acts

Data Retention and Investigatory Powers Act 2014, https://www.legislation. gov.uk/ukpga/2014/27/contents/enacted (data dostępu: 20.01.2021).

Konwencja o Ochronie Praw Człowieka i Podstawowych Wolności sporzadzona w Rzymie dnia 4 listopada 1950 r., zmieniona następnie Protokołami nr 3, 5 i 8 oraz uzupełniona Protokołem nr 2, Dz.U. 1993 nr 61, poz. 284.

Rozporządzenie Ministra Spraw Wewnętrznych i Administracji $z$ dnia 22 lipca 2016 roku w sprawie w sprawie katalogu incydentów o charakterze terrorystycznym, Dz. U. 2016, poz. 1092.

Ustawa $z$ dnia 10 czerwca 2016 roku o działaniach antyterrorystycznych, Dz. U. 2016, poz. 904.

Ustawa $z$ dnia 6 kwietnia 1990 r. o Policji, Dz. U. 2020, poz. 360 t.j.

Strony internetowe / Websites

Binney W., Podstuch rzadzi strachem (wywiad przeprowadzony przez E. Siedlecka i K. Szymielewicz), http://wyborcza.pl/magazyn/ 1,124059,17924695,Podsluch_rzadzi_strachem.html (data dostępu: 10.08.2020).

Francja poszerza kompetencje służb, https://panoptykon.org/wiadomosc/ francja-poszerza-kompetencje-sluzb (data dostępu: 10.04.2021).

PAP/IS24, Francja przedłuża obowiazywanie kontrowersyjnej ustawy antyterrorystycznej, https://www.infosecurity24.pl/francja-przedluzaobowiazywanie-kontrowersyjnej-ustawy-antyterrorystycznej (data dostępu: 20.12.2020).

Regulation of Investigatory Powers Act 2000, https://www.legislation. gov.uk/ukpga/2000/23/contents (data dostępu: 20.01.2021). 
Stasik E., Niemcy: Ustawa antyterrorystyczna $w$ znacznym stopniu niezgodna $z$ konstytucja, https://www.dw.com/pl/niemcy-ustawaantyterrorystyczna-w-znacznym-stopniu-niezgodna-z-konstytucj\%C4\%85/a-19201601 (data dostępu: 10 kwietnia 2021).

Ustawa antyterrorystyczna - skuteczne $i$ sprawne działanie służb, https:/ / mswia.gov.pl/pl/aktualnosci/14490,Ustawa-antyterrorystyczna-skuteczne-i-sprawne-dzialanie-sluzb.html?search=83945 (data dostępu: 02.09.2020).

Wielka Brytania: Wyrzekanie się wartości $w$ obliczu terroryzmu, https://www.liberties.eu/pl/stories/wyrzekanie-sie-wartosciwielka-brytania/3019 (data dostępu: 8.04.2021). 